\title{
International Commission
}

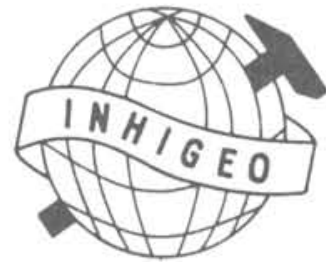

One very active member of the IUGS family is its

International Commission on the History of Geological

Sciences. It is fitting that a profile of INHIGEO should be included in Episodes 10 years after its first appearance in March 1978, for the opening article in that first issue was also on a historical theme by Gordon Craig. (Ed)

\section{The Background}

"History is bunk" said Henry Ford, but after he died he quickly became an important part of the industrial history of the United States of America. Perhaps geologists have learned to be more cautious in their view of matters historical, for most earn their living by interpreting the past - provided that it occurred millions of years ago. The study of mankind seems to be more appropriately dealt with by archaeologists and anthropologists. Old books, papers, letters and manuseripts are fodder for historians, who by association are supposed to be as old and dusty as their books. Yet the number of publications devoted to the history of geology shows rapidly inereasing activity among scientists and historians in this discipline. Why?

By its very nature geology has a strong historical aspect. Students are taught to think in the four dimensions of space and time. Perhaps then we should not be too surprised to

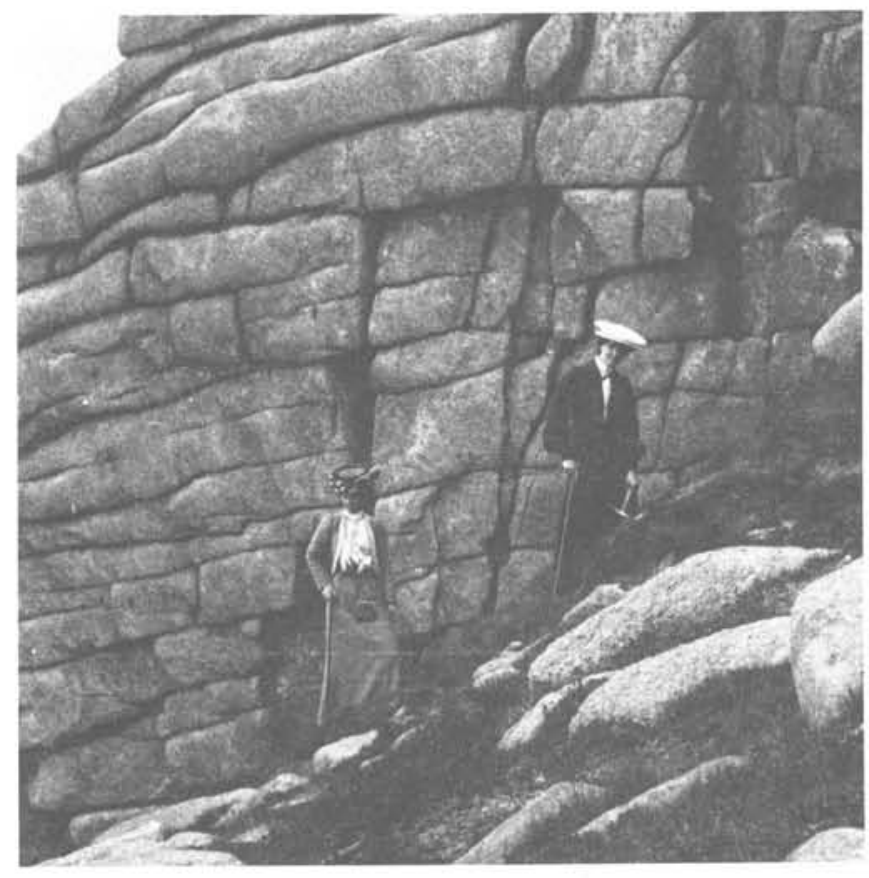

Figure 1: A granite tor on the Isle of Arran, Scotland, being visited in 1905 by two young geologists. This is a classical geological locality for the study of granite. Note that the hammer is held by the leader and the purse strings by the observer. Times have not changed.

\author{
by Gordon Y. Craig and Endre Dudich
}

find a latent interest in the history of geology in most geologists. Although geology is a young science with its roots in the 19th century, Lyell (1830-33) was able to find ample material to review the history of geology in his wellknown textbook and by the end of that century two popular books on the history of geology had been published (Geikie, 1897 and Zittel, 1899). The many articles and books that have appeared since then give a clearer perspective to what we have traditionally been taught. A good start can be made with two incisive short articles by Greene (1985) and Hooykaas (1982) who reveal all too clearly the methods and unconscious chauvinism of past and present historians and geologists.

\section{INHIGEO is Born}

The history of geology became formally organized in the second half of the 20th century. INHIGEO was conceived at the 1964 International Geological Congress in Delhi, on the initiative of Professor V.V. Tikhomirov, its founder President. The child was born as an IUGS Commission in Yerevan, U.S.S.R., in 1967 and like all infant committees was dutifully given aims and bye-laws by its doting parents. :The bye-laws affect the conduct of the Commission; the aims are of wider interest. They are intended to promote studies in the history of the geological sciences and to stimulate and coordinate the activities of national and regional organizations that have the same purpose. These aims are met primarily through the holding of symposia and the publication of works on the history of geological sciences.

TABLE 1: Membership of INHIGEO as of January 1988

\section{President}

Secretary-General

Vice-Presidents

Past President

G.H. Davies (Ireland)

D. Ellenberger (France)

G.K. Georgiev (Bulgaria)

M. Guntau (G.D.R.)

A.S. Kleczkowski (Poland)

W. Kupsch (Canada)

W. Langer (F.R.G.)

L.M. Lopez de Azcona (Spain)

\section{G.Y. Craig (U.K.)}

E. Dudich (Hungary)

T.G. Vallance (Australia)

V.V. Tikhomirov (U.S.S.R.)

R. Hooykaas (The Netherlands)

\section{Full Members}
U. Marvin (U.S.A.)
M. Masson (Switzerland)
N. Morello (Italy)
S.K. Mukerjee (India)
G. Regnell (Sweden)
J. Urban (Czechoslovakia)
Xia Xiangrong (China)

The affairs of the Commission are in the hands of the President, Secretary-General, the Past President, two Vice-Presidents and up to 22 Full Members, all from different countries (Table 1). In addition there are some 90 Corresponding Members, representing 33 countries. INHIGEO is also affiliated to the International Union on the History and Philosophy of Science - an important two-way link! 


\section{The Commission's Activities}

The first INHIGEO symposium was held in Yerevan in 1967 under the umbrella title of "History of Geology" as was the second symposium during the ill-fated Congress in Prague the following year. Table 2 lists the major topics at subsequent INHIGEO symposia.

At the 28th IGC in Washington in 1989, INHIGEO will co-sponsor symposia on several topics. The first will deal with the idea of time in discussion of "Changing concepts of the antiquity of mankind and the Earth." The second symposium will review the origin, distribution and adequacy of mineral and energy resources with an "Historical evaluation of geologic, mining and environmental perspectives." Other symposia will address "The trans-Atlantic exchange of geological ideas during the 19th century," and "Meteorite impact: consequences for the history of geological ideas."

\section{TABLE 2: Main Topics of INHIGEO Symposia}

1967 Yerevan, U.S.S.R. - History of geology

1968 Prague - History of geology

1970 Freiberg - History of concepts of mineral deposits

1972 Montreal - History of concepts on Precambrian geology

1974 Cordoba, Spain - History of teaching geological sciences

1975 London, Oxford - Charles Lyell centenary

1976 Sydney - The growth of geological knowledge in the age of geographical exploration

1978 Munster, Bonn - Regional influences on the origin and development of geological theories

1980 Paris - The development of the geological sciences up to 1832 , and works in the French language in the international exchange of ideas

1982 Budapest - The development of geological mapping in connection with progress of geological thought

1984 Moscow - History of mineralogy

1985 Edinburgh - The influences of scientific organizations on the development of geology

1987 Pisa-Padova - Rocks, Fossils and History (See Hala, 1987, and conference report by Hamilton in this issue)

In the next decade we look forward to forging closer links with China, India and Japan and very much hope that at least one will be prepared to act as host to an INHIGEO symposium, for it is high time that one of our meetings took place outside the western hemisphere. Active national committees on the history of geology are a great help in this respect. They now exist in Australia, Bulgaria, Czechoslovakia, Federal Republic of Germany, France, German Democratic Republic, Hungary, Italy, Poland, Rumania, Spain, United Kingdom, the U.S.A. and the U.S.S.R. Others may well be alive and well, but we have not heard from them officially. Some have their own news-sheet, and all are invited to contribute to the annual INHIGEO Newsletter, which will celebrate its 21st birthday in 1988. This has a print run of 1200 copies, and although it is widely distributed it is not yet as effective a source of news and views as it might be.

\section{Commentary}

There can be no doubt that interest in the history of geology is booming. Historical books and papers multiply; festschrifts, conferences, anniversaries and other meetings frequently have a specific historical input, and a society expressly created to study the history of earth sciences HESS - was formed in 1981. Traditionally a respectful length of time has elapsed between death of a major figure or event and a measured historical appraisal, although such "respect" may also reflect the delay in the release of confidential public records. Such leisurely reviews are now being supplemented by audio-visual impressions of major historical events (almost as they happen) by the chief protagonists involved.

Despite all this activity, there are relatively few philosophers, historians or scientists specifically employed to work in this field. We know of 25 in the U.S.S.R., 10 or so in the U.S.A., a handful in France, West Germany and the G.D.R., and one each in Australia, Italy and the U.K. We are all painfully aware that funds come more easily to those who can argue that a quick economic return for an investment is possible - although a study of history shows that that is frequently not the case!

The history of geology attracts both "amateurs" and professionals alike, because it is both interesting and exciting. There is always the chance during a library search, of a new find, a new slant on an old problem, or an insight into why individuals behaved (or misbehaved) in a particular way. And geologists who go on excursions to classical geological sites are both learning geology and reliving its history (Fig. 1),

After the 27th IGC meeting in Moscow, one of the authors was subjected to hard questioning. Why should one study the history of geology and what it had achieved? Indeed, what could it possibly teach the interrogator? In response we quoted the short and unanswerable reply given by Professor R. Hooykaas, our distinguished past-president, to the same question - "Humility." Whether you agree with him or not we invite you to do a little historical research of your own.

Prof. G.Y. Craig, the President of INHIGEO, retired recently from the Grant Institute of Geology at the University of Edinburgh (West Mains Road, Edinburgh EH9 3JW, U.K.). Prof. Craig is well known for his work on the geology of Scotland and his interest in the history of geology.

Dr. E. Dudich heads the IGCP Secretariat (Unesco SC/GEO, 1, rue Miollis, B.P. 3.07 , 75015 Paris, France), where he keeps track of the activities of projects the world over. The former Deputy Director of the Hungarian Geological Survey, he is also INHIGEO Secretary.
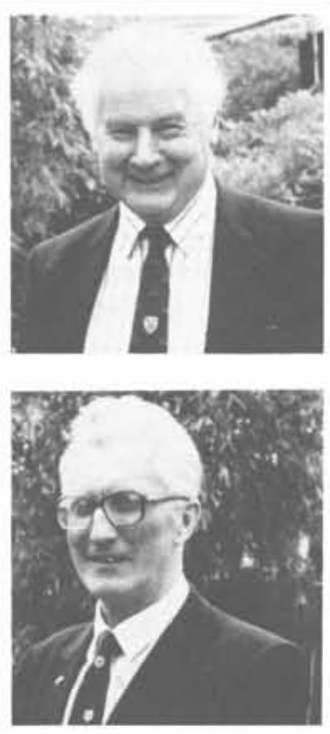

\section{References}

Geikie, A. 1897. The Founders of Geology. Macmillan, London, 297p.

Greene, M.T. 1985. History of Geology. Osiris, 2nd series, v. 1 , p. $97-116$.

Hala, J. (ed.), 1987. Rocks, fossils and history. ItalianHungarian relations in the field of geology. Papers from the 13th INHIGEO Symposium, Pisa-Padova, 1987. Hungarian Geological Society, 333p.

Hooykaas, R. 1981-82. Pitfalls in the historiography of geological science. Histoire et Nature, no. 19-20, p. 21-34.

Lyell, C. 1830-33. Principles of Geology, vols. 1-3. J. Murray, London.

Zittel, K.A., von, 1899. Geschichte der Geologie und Paläontologie bis Ende des 19 Jahrhunderts. R. Oldenbourg, München und Leipzig, $868 \mathrm{p}$. 